\title{
MYTHICAL ELEMENTS IN THE SAMSON STORY.
}

\section{INTRODUCTION.}

OME time ago, in connection with Mr. Evans's study
of the mythical Napoleon, I made some editorial comments on myth in history, and alluded incidentally to the Biblical legend of Samson as a solar hero. I deemed this theory thoroughly established and was quite astonished to be called to account by Mr. George W. Shaw, one of our readers and contributors, and a good Hebrew scholar to boot, well versed in Bible lore. ${ }^{1}$ I must further admit that $\mathrm{Mr}$. Shaw is not isolated in his opinion, for not only Biblical encyclopædias, both German and English, but also the best secular works, ${ }^{2}$ such as the Encyclopaedia Britannica, repudiate the idea that the story of Samson should be a myth. These circumstances made me reconsider my opinion, but after all, I do not feel compelled to make any radical change in my views. Having collected the evidence, I find that the case is very instructive because it throws much light on the religious development of the Bible.

Mr. Shaw's challenge is the immediate cause of the present treatise, and I am grateful to him for his protest.

"An article of his entitled "The Period of the Exodus" appeared in The Monist for April, I906.

2One quotation shall suffice: "Der Versuch Samson als den phönizischen Herakles, den Sonnengott, zu erklären, scheitert an konkreten Einzelheiten und den lokalen und nationalen Motiven der Sage." Brockhaus, Konversations-Lexikon, Vol. XIV, p. 991. 
I have devoted considerable time to a reconsideration of the problem, but to re-read the story as told in the Bible, to compare doubtful passages with the original Hebrew, to peruse critically and with care what has been written on the subject by my predecessors in this field (especially Roskoff and Steinthal), to make a résumé of the old arguments, to add some new ones which I discovered by the way, and finally to condense and rearrange the entire subject in the present essay, has been a genuine pleasure to me. I only wish that the perusal of it all will be as interesting and instructive to my readers as the writing of it was to me.

I will say at once that Mr. Shaw's position contains a truth which I do not mean to question, and which I had insisted upon from the start. An account which is decked with mythological arguments should not for that reason be regarded as absolutely unhistorical, for it is quite natural that myth enters into the fabric of history, as I have pointed out in my introduction to Mr. H. R. Evans's book on the Napoleon myth. ${ }^{3}$ Yet, if, on the other hand, a myth has crystallized in a definite form and localized in well-known places, we must not jump to the conclusion that its historicity is well established. It is true, as Mr. Shaw remarks, that "thinkers are becoming more anxious to find history in myth," but one reason why our critics are returning to a conservative consideration of traditions after a period of hyper-criticism, is given in the counterstatement, also alluded to by $\mathrm{Mr}$. Shaw, that they "detect myths in history." It is so natural for man to associate things of the same type that the deeds of a hero are told and retold with reminiscences of the mythology of his ideal, his tutelary patron saint, or god, and thus the two stories, fact and fancy, history and myth, are imperceptibly fused

'The Napoleon Myth. Chicago: The Open Court Publishing Co., 1905. 
until the hero is deified and the historical tale changed into a myth.

The story of Samson is of special interest and perhaps more instructive than any other legend or fairy tale in the Old Testament; but that it is legend and not history must after all be conceded by all exegetists and higher critics, both liberal and orthodox. It seems to me out of the question that there is any one who would believe the story literally, or lay much stress on the Biblical account as inspired by the Holy Ghost. If there be any one left who is naive enough to take the old orthodox standpoint with respect to the Samson story I should, indeed, like to know how he can make his conception of God agree with the lack of dignity and decency displayed in these primitive traditions.

\section{ROSKOFF AND STEINTHAL.}

The first to devote a special investigation to the legend of Samson was Dr. Gustav Roskoff, professor of Protestant theology at the University of Vienna, who in 1860 published an essay on the Samson legend, its origin, form and significance compared with the Heracles myth, ${ }^{1}$ and I have found him still quoted as an authority upholding the historical character of the Hebrew hero. He does so indeed, but not without serious limitations. Conservative writers who rely on him usually overlook the fact that Roskoff treats almost every single incident of the narrative as legendary and merely claims that there are "factic moments"2 in the story. Whenever he discusses details he alludes to them as "impossibilities and incredibilities" which "in legends" are a matter of course, excusing them with such words as (page 67) "The saga does not care for the credibility of the represented events or related items." He accepts Samson's nazirdom, his heroism, and

${ }^{1}$ Die Simsonsscge nach ihrer Entstehung, Form und Bedeutung, und der Heracles Mythus. Leipsic: I860.

${ }^{2}$ The original reads: faktische Momente, page 39. 
his death as "factic elements," but that is all, so far as I can see; for he says, "The legend (Sage) elevates the hero at the cost of details and historical by-work, and the higher he rises the more neglected are the latter" (page 76). Roskoff argues "Legend is a child of the heart ( $\mathrm{Ge}$ müth) and knows no reflection" (page 7I); he suggests that the narrator and his hearers were not critical, and thus the legend finds no difficulty in the strange ignorance of Delilah who ought to have known that Samson was a Nazir and ought to have been familiar with the mysterious quality of his hair (page 7I). Roskoff goes so far as to concede that the "sidereal relation permeates the entire Samson saga" (p. IIO), but he claims that this pagan feature of it "has been overcome by the idea of Yahveh." Roskoff's concessions grant the whole case and so the believers in the historicity of Samson can hardly claim his authority for a denial of the mythical character of the story. The Yahveh idea is to him the saving element which renders the story religious and makes the historicity of some of its moments probable; and yet even this is of a doubtful value, for Roskoff admits that "the spirit of Yahveh comes over Samson and gives him strength to accomplish his deeds not otherwise than Homeric heroes are assisted by the gods" (page 45). Such is the view of a professor of theology who interlards his expositions now and then with pious contemplations!

Prof. H. Steinthal, of the University of Berlin, criticizes Roskoff severely for his theological bias. He blames him especially for calling Samson "the hero of prayer" (p. 70) who prayed to Yahveh and whom Yahveh helped; but Professor Steinthal is unfair in not allowing his predecessor the right to apply the story in his own way. Do not the Greeks of classical antiquity and modern admirers of Greek culture see in Heracles the ideal man, and so why should not Roskoff, a believer in Biblical traditions, 
idealize the hero of the Jews in a way to suit his personal preferences? Though Steinthal is perhaps more at home in the field of comparative folklore, being one of the founders of this branch of learning, his own essay on Samson scarcely contains much more as to the facts and perhaps not fewer points for criticism than Roskoff's little book.

HOW MYTH AFFECTS HISTORY.

The Romance of Alexander is a mediæval epic which echoes the impression made by the great conqueror on the people of Asia. It incorporates many adventures of the Babylonian Izdubar epic and so the origin and history of this strange literary document is very instructive and shows how easily history and myth are fused into romance. $^{1}$

The romance of Alexander tells us about his adventures in many strange countries, and of his struggles with wondrous monsters of all descriptions, reminding us of the incidents of the legends of Heracles, Odysseus, Eneas and other solar heroes, and the interest in these fantastical narrations continues down into the middle ages. We reproduce here some of the illustrations of a manuscript written and illumined in the thirteenth century, in which the history of Alexander of Macedon has been absolutely obliterated by mythological reminiscences incorporated into this romance.

Might not one literary critic rightly say that the Romance of Alexander is the Izdubar myth told of Alexander, and that it is originally a solar myth, while another would deny this proposition and claim that the hero of the romance is historical though the account is overlaid with mythical ornamentation? What would be the difference between these contradictory theories beyond mere words?

\footnotetext{
${ }^{1}$ Nöldeke, Beiträge zur Geschichte des Alexander-Romans, Vienna, I89o; and Meissner, Alexander und Gilgamesch, Leipsic, 1894.
} 


\section{THE LOCALIZATION OF MYTHS.}

The Romance of Alexander is not an exception but a typical instance of the historization and localization of a myth. The Nibelung Saga is thoroughly localized on the banks of the Rhine and the Danube, and is connected with actual figures of history such as Attila. The Heracles myth definitely points out the places where Heracles was born and where he accomplished his mighty deeds. The royal families that traced their descent from him were still flourishing in historical times, and the "Pillars of Heracles" are standing to this day. The same is true of all myths and legends, of the Osiris myth in Egypt not less than the anecdotes told of Luther, Frederick the Great, Napoleon and other modern heroes. Even the fables related of the devil, are localized without any equivocation; the stones he threw, the bridges he built, the walls he piled up are still pointed out, and if the testimony of these actual traces of his activity as corpora delicti are accepted as evidence. we can not deny the historicity of the stories.

The historicity of Samson is accepted on no other ground. Dr. Gustav Baur, for instance, sums up his argument in Riehm's Handwörterbuch des Biblischen Altertums, - a standard work of German theology, as follows:

"Against the thorough mythization of this Biblical tale speak the definite localities to which Samson's birth, deeds and destinies are attached, and which in any attempt at a mythological solution will remain an insoluble residue, pointing decidedly to a definite historical tradition."

The Encyclopaedia Biblica, the most scholarly and critical theological work of reference in the English language, gives a similar verdict:

"Though the name means 'solar,' neither name nor story lends any solid support to Steinthal's idea that the hero is nothing but a solar myth. (Wellhausen, whilst 
he rejects Steinthal's myth theory, also denies Samson's historical character.) He is a member of an undoubtedly historical family of those Danites who had their standing camp near Zorah, not far from the Philistine border, before they moved north and seized Laish. The family of Manoah has a hereditary sepulchre at Zorah, where Samson was said to lie, and their name continued to be associated with Zorah even after the exile, when it appears that the Manahethites of Zorah were reckoned as Calebites. The name had remained though the race changed (1. Chron. ii. 52-54.)."

We grant the argument, but we grant it as well for Homer's epics. The geographical background of the Odyssey is historical and among the adventurers of the Homeric age there may have been a man who bore the name Odysseus. At any rate, there were plenty of adventurers like him, yet we do not see how the concession refutes the truth that the Odyssey reflects the myth of the sun's migration. It is a myth changed into saga, or if you prefer, a saga based upon a mythical motive.

With the same argument we can easily prove the historicity of Münchhausen's adventures, for the family of Münchhausen still prospers in Germany, and the stories contain many allusions to definite historical and geographical conditions.

If we speak of history we ought to mean history pure and simple, unadulterated by mythical elements; and if we ask whether or not the Samson story is historical, taking the word seriously I do not see how any one-scholar or not scholar-can answer in the affirmative.

THE PHCENICIAN MELKARTH.

We have reliable information that the Phœnicians celebrated Melkarth's death and resurrection on two distinct days of their festive calendar. The commemoration of the 
god's self-sacrifice on the pyre was still celebrated in the days of Dio Chrysostom in an annual feast at which the god's effigy was burned on a gorgeous pyre; and Professor W. Robertson Smith quoting this statement from O. Müller adds that it "must have its origin in an older rite, in which the victim was not a mere effigy but a theanthropic sacrifice, i. e., an actual man or sacred animal, whose life according to an antique conception was an embodiment of the divine human life." The story of Sardanapalus and kindred legends are merely survivals of the Melkarth myth as has been pointed out by $O$. Müller in his article "Sandon und Sardanapal."

The festival of the resurrection of Melkarth was celebrated annually in the month of Peritius which falls at the end of February and the beginning of March, at the time when the quail returns to Palestine, coming in immense crowds in a single night $;^{2}$ and according to Eudoxus $^{3}$ a quail sacrifice was made to commemorate the resurrection of the god.

Every myth of deep religious significance has the tendency to change into saga or legend, and will even influence history. Myths are frequently humanized by being ascribed to a national hero, or to some prominent historical person. But it also happens that some pious man is influenced by the ideas of his religion and actualizes in his life the lesson which his faith has installed into his heart. This is seen in the following incident recorded in Herodotus VII, I67. There the Greek historian tells of the Carthaginians fighting with the Greeks in Sicily in a battle which lasted the whole day from morning until night; and that Hamilcar, anxious to gain a decisive victory, offered holocausts on a great pyre, but when he saw that his people were routed, leapt into the fire himself and sacri-

${ }^{1}$ Rhein. Mus., Ser. I, Vol. III. 'Jos. Ant. VIII, 5. 3.

${ }^{3}$ Quoted by Athen, IX, 47. 
ficed his life for the good of his people. Thus he was burned to death and disappeared, and Herodotus adds: "In this way Hamilcar may have disappeared as is stated by the Carthaginians, or it may have been different as say the Syracusans, but this much is sure that the Carthaginians offer him sacrifices, and have erected monuments in his honor in all their colonies, though the greatest of them is in the city of Carthage."

Some scholars think that Herodotus here confuses the Carthaginian hero with his god and transfers the myth from Baal Melkarth upon Hamilcar; but whether or not the incident is to be accepted as historical, it proves the power of myth and the influence of religious conceptions upon the actual life of the people.

\section{THE TWELVE LABORS.}

According to Dr. Gustav Roskoff (loc. cit., pp. 2230) the twelve labors of Samson are as follows:

I. He kills a lion with his hands. It is characteristic of Samson as well as of Izdubar, the Babylonian solar hero, and also of Heracles, that the lion is slain without the use of any weapon.

2. At his marriage at Timnath he proposes a riddle. and incidentally slays thirty Philistines at Ascalon.

3. He catches three hundred foxes and chases them with firebrands through the fields of the Philistines.

4. The Philistines burn his wife and his father-in-law's whole family which induces him to make great slaughter among them, whereupon he flees into the mountains of Judah and hides in the cleft of the Cliff Etam.

5. Samson is bound by the men of Judah and delivered to the Philistines who take him to Lehi, but "the ropes on his arms became like flax that has caught fire."

6. Samson picks up the jawbone of an ass and kills multitudes of his enemies. 
7. Being overcome with thirst he prays for water and a spring breaks forth from the ass's jawbone.

8. When visiting a woman at Gaza, he escapes the ambush of the Philistines by rising at midnight and carrying with him the two doors of the city gate, which he plants upon the hill which is in front of Hebron.

9. Now he became entangled with Delilah. The treacherous woman bound him with seven new bowstrings, but when the Philistines came upon him "he snapped the bowstrings as a strand of tow snaps at the breath of fire."

Io. Thereupon Delilah bound him with seven new ropes, but he "snapped the ropes off from his arms like thread."

II. Delilah weaves the seven braids of his hair into the web of her loom, but he pulled up the loom with the web and escaped the third time.

I2. Finally Samson betrays the secret of his strength, and Delilah had the seven braids of his hair shaved; he was taken prisoner and blinded. But when his hair had grown again his strength returned and enabled him to break down the two pillars of the Dagon temple by which deed he buried himself with multitudes of his enemies under the ruins of the edifice.

We do not lay much stress upon this division of Samson's career into twelve adventures which would make their number agree with the twelve labors of Heracles and the twelve months of the year, but it is remarkable enough that this proposition is made by Roskoff who is so conservative as to be the main authority for the historicity of the Samson story.

THE LION AND THE BEE.

Some features of Samson's adventures are noteworthy. The lion symbolizes the heat of the sun and is but another symbol of the sun-god himself, but the mollification of the 
solar heat is attributed to the sun-god, and so he is celebrated as the slayer of the lion.

The riddle concerning the honey in the carcass of the lion has proved a puzzle to all who still believe in literal inspiration. Bees will never make their habitation in dead animals and the form of the riddle indicates that the text has been greatly corrupted. The riddle is not a question but a statement-a positive proposition. It reads:

"Out of the eater comes something to eat;

And out of the sour ${ }^{1}$ one comes something sweet."
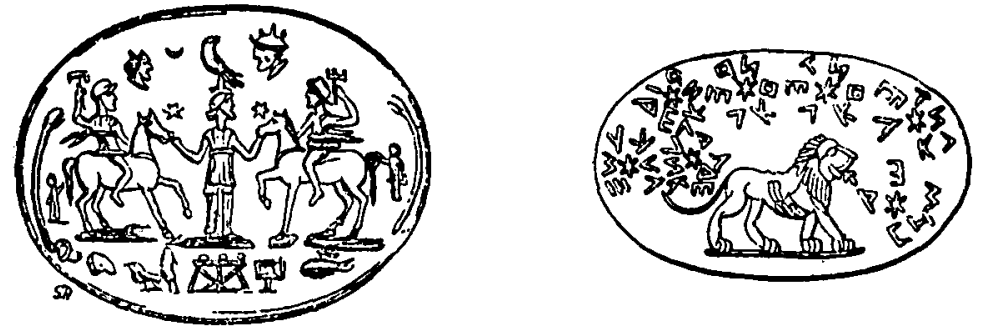

MITHRAIC PLAQUE. ${ }^{2}$

And the answer is stated in the form of a question, thus:

\section{"What is sweeter than honey, and What is more sour ${ }^{1}$ than a lion?"}

It can only be regarded as a solution by doing violence to the meaning. The connection between the bee and the lion must have been known to the audience to whom the riddle was proposed, and so the very impossibility of the fact as a real event of life must have added to the interest of the solution.

There is an ancient Mithraic plaque representing a

1 "Sour" or "strong."

2 The obverse of the medal shows Mithra between Castor and Pollux; above his head the raven and other Mithraic symbols. Underneath, the altar with the sacramental bread, the cup of the eucharist, the fish, the dove, etc. The reverse shows in the center a lion with a bee in his mouth. $\mathrm{He}$ is surrounded by seven stars with illegible inscriptions. 
lion with a bee in his mouth and the simple explanation of it may be nothing more nor less than that the bees produce honey in the lion, i. e., the month when the sun stands in the sign of Leo. Thus it would be quite plausible for an ancient riddle to propound the paradox, "When or where can honey be found in a lion?" And the answer, alluding to the deed of the sun-god, would be: "In the month of the slain lion." Accordingly the strange thing comes to pass that

"Out of the eater comes something to eat;

And out of the sour one comes something sweet."

That the original meaning of the riddle has been obliterated in the Samson story is but natural when we consider the redactor's tendency to cut out mythological references.

\section{THE FOXES WITH FIREBRANDS.}

The story of the three hundred foxes appears in its true light when we consider it as a parallel to the Roman custom of chasing foxes with firebrands through the circus on the festival of Ceres, an ancient patrician ceremony which, however, was so popular that it had been customary for the plebeians to take part in it as guests. On the main day (according to Preller, April I9) small gifts were thrown among the crowds, usually eatables, among which nuts are specially mentioned. There were no horse races, but red foxes with firebrands tied to their tails were chased through the arena. It is understood that they signified the cereal disease of robigo, for the word means "red fox." as well as the red blight of wheat.

Ovid (Festi IV, $679 \mathrm{f}$.) tells the story of a peasant of Carseoli which is intended to explain the origin of the custom. A rustic couple had a son of about twelve years who caught a fox that had frequently stolen hens. The boy wrapped him in straw and hay and set fire to it. The 
fox managed to escape and retreated into the wheat fields, igniting the whole harvest. Thereupon a law was passed that every captured fox should be killed and the foxes were punished in the Cerealia as above mentioned. ${ }^{3}$

We cannot doubt that this coincidence between Samson's foxes with fire-brands and their Roman counterparts is not accidental, but both are distant echoes of a most primitive notion which in other parts of the world has been lost.

\section{SEMELE AND DIDO.}

It is not uncommon in ancient mythology for brides of solar heroes to be burned in fire, as Semele dies through the awful presence of Zeus. Accordingly, if Samson's wife is burned together with her father's family, it is quite in keeping with the general character of our myth however improbable it might be in a historical story.

We have repeatedly mentioned Eneas as one of the solar heroes, and will say that evidence of his character is found not only in the fact that he is the son of Venus, nor in his migration over the whole world, nor alone in his descent into Orcus, the realm of the dead, but also in that particular incident of having a bride who dies in the fire as a holocaust. When Æneas comes to Carthage he falls in love with Dido, but at a divine command he leaves her, which causes her in her despair to commit suicide, and burn herself on the pyre as a victim of her love.

Virgil's version of the death of Dido is a comparatively late modification of an older legend, alluded to by the historian Timæus and by Justinus, ${ }^{1}$ according to which Dido

${ }^{8}$ For detailed references and further information of kindred practices especially the worship of Robigo in the grove of Robigo, also the Bootian story of the dog Kephalos and the Teumessian fox, and the Roman custom of sacrificing young dogs of red color at the time of the dog-star on the road to Nomentum, see L. Preller's Römische Mythologie, 3rd edition by H. Jordan, Berlin, 1883, Vol. II, pp. $43 \mathrm{ff}$.

${ }^{1}$ Fragm. Hist. Gr., ed. Mueller, I, 197; and Justinus XVIII, 6. Compare W. R. Smith's Religion of the Semites, (London, I90I), p. 374. 
sacrifices herself for her husband Sicharbas. Prof. G. Hoffmann (in his Phoenicische Inschriften, p. 32 f.) points out that she is the goddess Tanith, the consort of Baal. and the word Sicharbas is the Phœnician Sichar baal. The word Sichar corresponds to the Hebrew dzecher ${ }^{2}$ which means "commemoration."

There is a whole class of legends on solar brides of which the story of Semiramis it typical. Like all these fantastic traditions, it is a myth that has been localized and by being transferred to an historical person changed into saga. The original form of the myth is still preserved in the tales of the death of Astarte at Aphaca and the suicide of Aphrodite, who after the death of Adonis threw herself down from the Leucadian promontory. ${ }^{3}$

\section{SAMSON IN HIDING.}

Steinthal calls attention to the fact that Apollo after having slain the dragon seeks refuge in flight, and Indra does the same after he has slain the monster Vritra. He also maintains that El, the highest Semitic God, must hide, and in the Samson legend we read that the hero in spite of his great victory over the Philistines flies and hides in the cleft at Etam (Chap. xv. 8). Steinthal regards this motif as a common trait of solar legends and explains it as due to the observation that after a storm which appears to be like a struggle between two powers of nature, a calm sets in, and this calm is interpreted to mean that the hero after his victory, retires and hides in some cleft or cave.

Steinthal's explanation does not appeal to us. Like some other theories of his it is far-fetched, and even if he were right, we think that in the Samson legend his

$37 ?$

'Ptol. Nov. Hist., VII, p. I98. Cf. W. R. Smith's Religion of the Semites, p. 375. 
hiding is not, as Steinthal claims, without sufficient motive. The Philistines were the masters of the country, and it was but the duty of the authorities to search for the bold murderer who, without sufficient provocation, had slain thirty men at Ascalon and still continued by indiscriminate slaughter to make the highways unsafe. The fact, however, remains that Samson hides-an event which is not uncommon in the career of solar heroes.

We must assume that when the Samson story reached its final form, the solar character of the hero had already been lost sight of, and so we can not expect that the details of Samson's adventures should be parallel to definite phenomena in the sun's course. But if we seek for an explanation of Samson's hiding, we would suggest that the sun hides behind the clouds, and the event takes place after an unusual heat, which means that the sun-god has emptied his quiver of arrows against his enemies. We note further that the hidden sun-god is supposed to be vanquished by his pursuers, but he bursts out on them with unexpected ferocity in a thunderstorm, and it is peculiar that in this special instance the sun-god is identified with the god of thunderstorms, a peculiarity which is most assuredly verified in the Samson legend, for when Samson is taken prisoner by the Philistines, he picks up the jaw-bone of an ass and slays a thousand of his foes.

THE JAW-BONE OF AN ASS.

The story of the jaw-bone of the ass has been localized, and it appears that a certain rock formation has been called Ramath-Lehi, i. e., "The Hill of the Jaw-Bone." The Hebrew narrator changes it to Ramah Lehi which means "he threw away the jaw-bone," saying that here Samson dropped his weapon.

It is noteworthy that the name "ass's jaw-bone" in 
Greek (i. e., Onugnathos ${ }^{1}$ ) is given to a promontory at the southern end of Laconia as Strabo informs us, (VIII, 5, I, p. 353), and we may assume that here, too, the name refers to the deed of some ancient hero now forgotten.

Jaw-bones, and especially the jaw-bones of asses (for

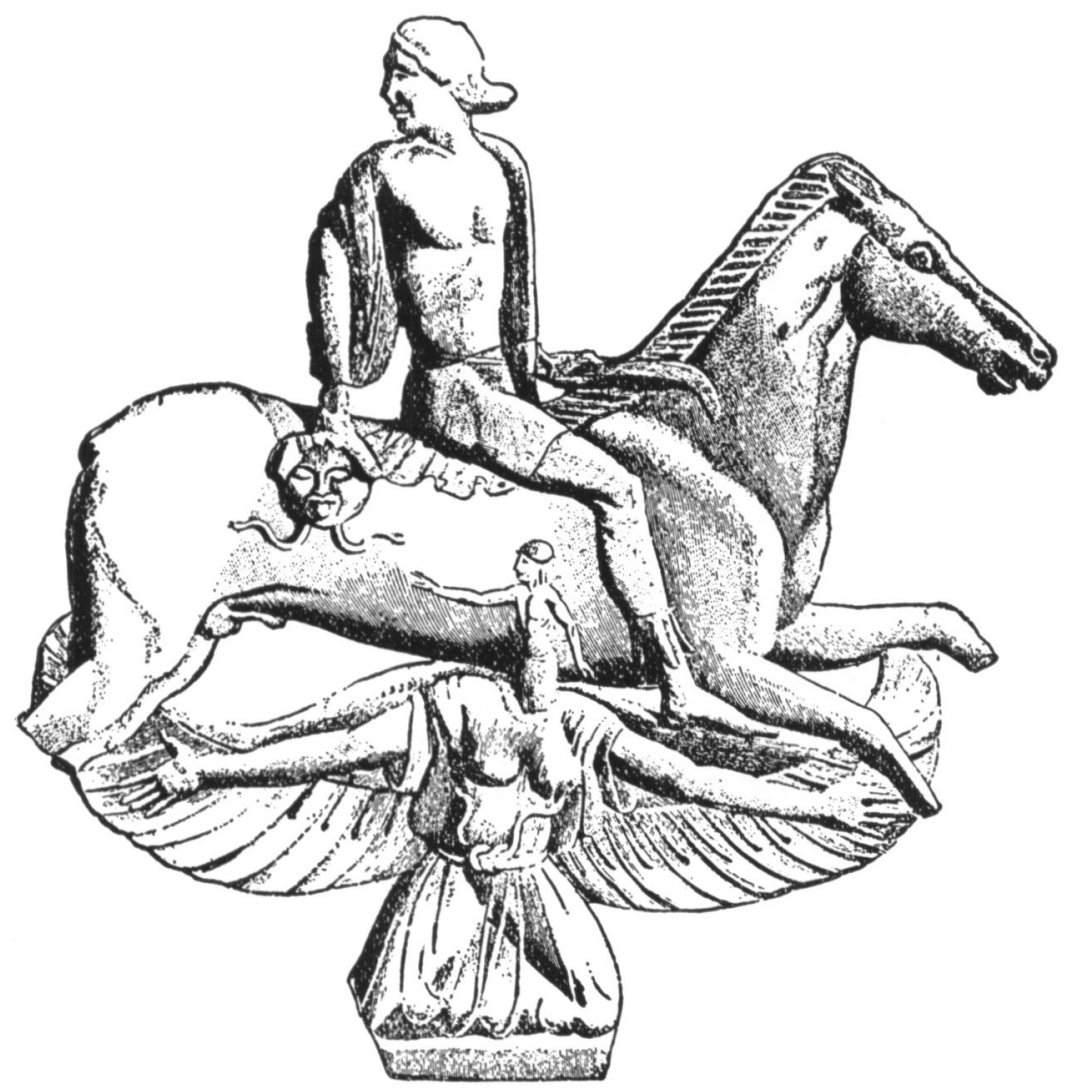

horses were not yet domesticated) were used in the paleolithic ages as weapons, and their form seems to have been retained for a while in the age of bronze, before the invention of the sword; for it is not improbable that the socalled "sickle-sword" of the ancient dragon-killers Bel 
Merodach and Perseus is but the primitive jaw-bone weapon made of bronze.

In the ancient bas-reliefs representing Bel Merodach's fight with Tiamat, the god is armed with thunderbolts, ${ }^{2}$

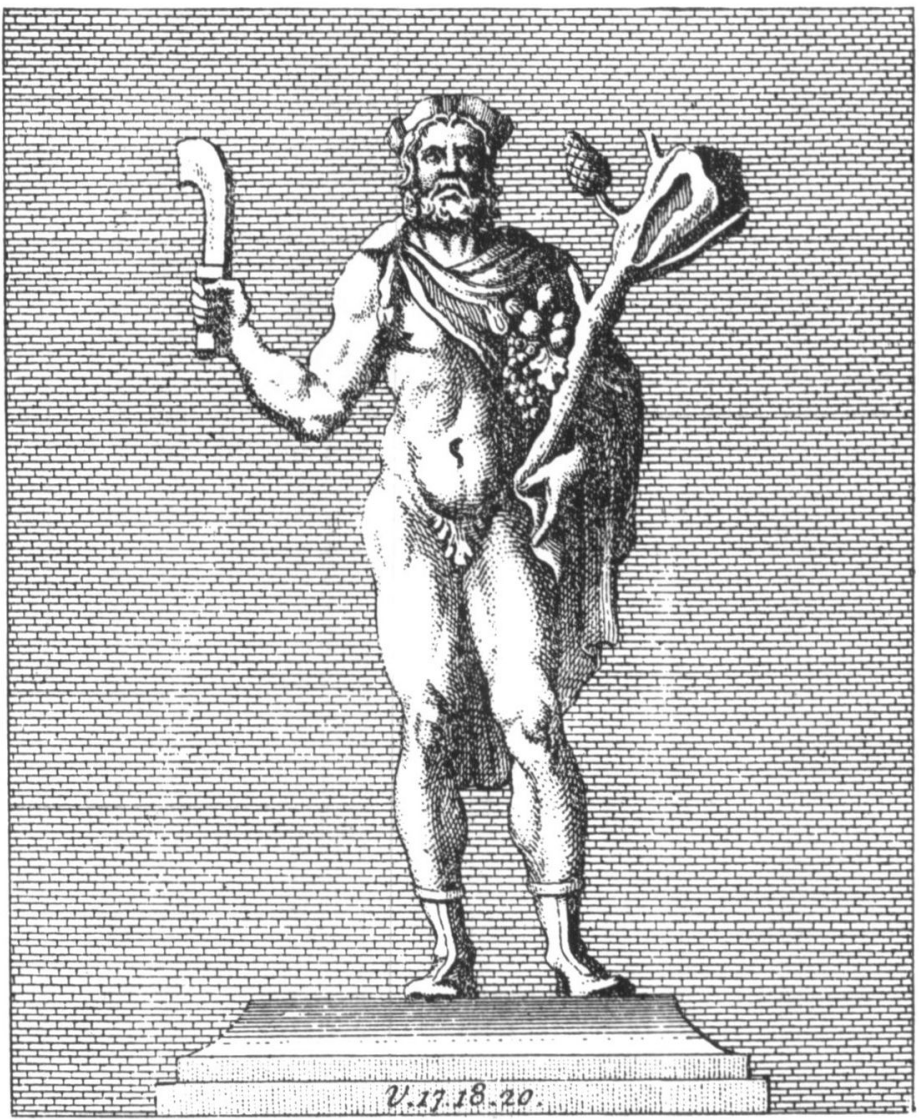

but in Table IV of the Creation story (lines $35 \mathrm{ff}$.), we learn that he carried a sickle-sword or falchion (from the Latin falx, a sickle). The lines describing his armament read as follows:

'See the author's History of the Devil, p. 4I. 
"He made ready a bow, Prepared it for a weapon, He armed himself with a falchion, Attaching it [to his belt] ; He took the god-weapon, ${ }^{\mathbf{B}}$ His right hand seizing it. Bow and quiver, He hung at his side. He caused a lightning-flash To precede him, Whose interior he filled With shooting flames."

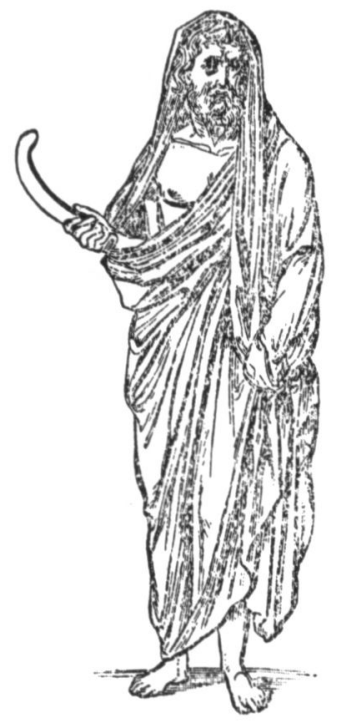

When speaking of sickle-swords we must consider that the ancient sickle was shaped exactly like a jaw-bone as may be seen for instance in the ancient representations of Silvanus whose common symbols are a sickle and a cypress branch. Later on both sickles and sickle-swords are replaced by instruments bearing the shape of a modern sickle.

Presumably lightning. 
Kronos, the most ancient among the gods, is also represented with a sickle-sword in his hand, and in the more archaic statues this sickle-sword, too, bears a strong resemblance to the ass's jaw-bone. If these data can be relied upon, we may fairly well assume that among some of the primitive folks, the sun-god's weapon was an ass's jaw-bone which accordingly would have to be identified with the thunderbolt.

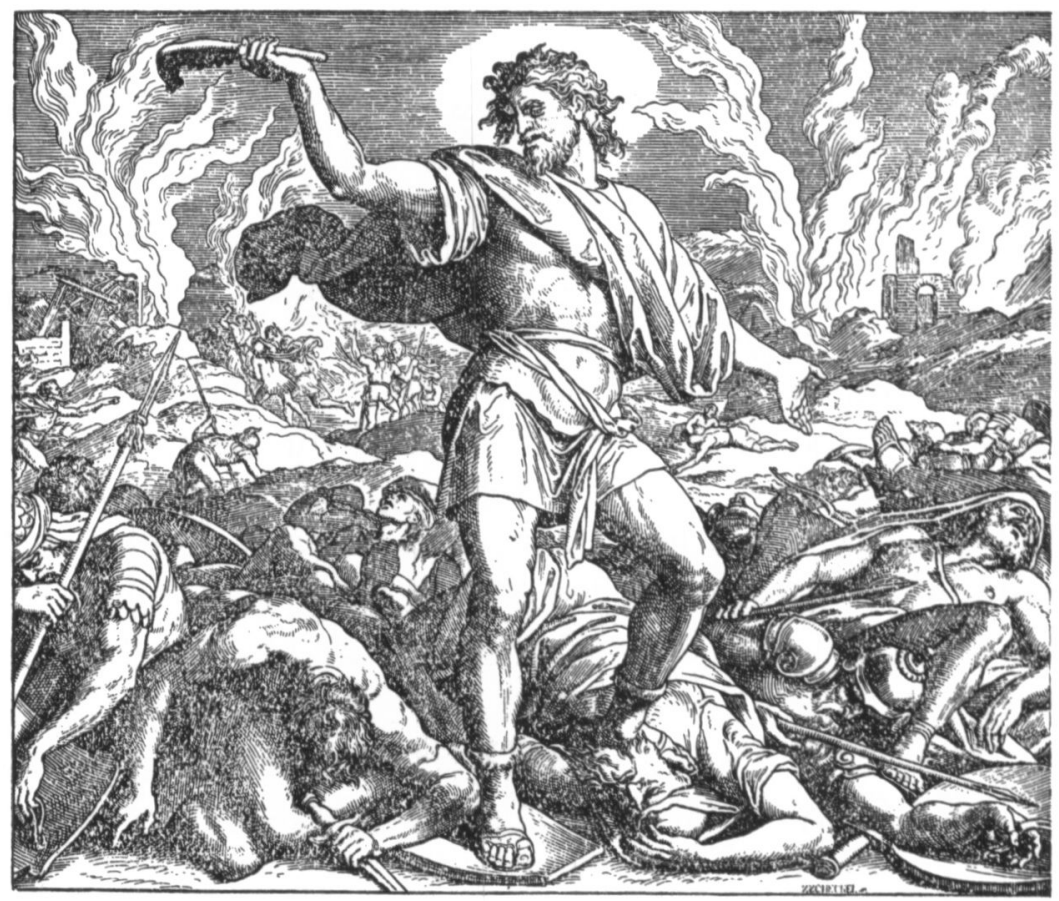

SAMSON SLAYING THE PHILISTINES.

By Schnorr von Karolsfeld.

Our explanation is further verified by one significant detail of the story which associates the jaw-bone closely with gushing waters. If the jaw-bone is the thunderbolt, we must expect that after its use there will be rain, and Guido Reni with his fine artistic sentiment still feels this interpretation when in his picture of Samson quenching 
his thirst from the drink that came from the jaw-bone he represents the water as rushing down from above, the hero holding the jaw-bone high above his head.

The Biblical story tells us of a fervid prayer of Samson which, being poetical in its wording, may be a quotation from an older version. But we may well assume that according to the ancient interpretation it must be regarded not in our modern sense of an orison but as a magic spell.

When the legend was localized, a spring in the hollow place of the Rock of the Jaw-bone was pointed out as the water which had come forth in answer to the prayer of the exhausted hero.

Diodorus Siculus (IV, 22) tells us that when Heracles wandered from Pelorias to Eryx, the nymphs on the road made the warm springs Himerea and Egestæa gush forth for his refreshment.

Before we proceed we will mention that Samson's shout of triumph concerning his successful slaughter contains a pun which renders the original almost untranslatable. The word khamor means both "ass" and "heap," and he exclaims at the height of his triumph:

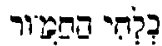

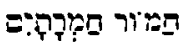

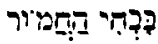

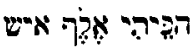

"With the jaw-bone of the khamor (ass)

A khamor (heap), two khamors (heaps)

With the jaw-bone of the khamor (ass)

I slew a thousand men."

It is interesting to see how translators have tried to reproduce the pun. A German scholar, E. Meier, translates as follows:

"Mit dem Backen des Packesels

Ein Pack, zwei Pack, 
Mit dem Backen des Packesels

Erschlug ich tausend Mann."

Professor G. F. Moore in the translation in the Polychrome Bible, translates the same passage very ingeniously as follows:

"With the jaw-bone of an ass

I assailed my assailants, ${ }^{5}$

With the jaw-bone of an ass

Have I slain a thousand men."

The well is called en haqqore, ${ }^{0}$ the "spring of the crier," which latter means "partridge" and is also an epithet of

49
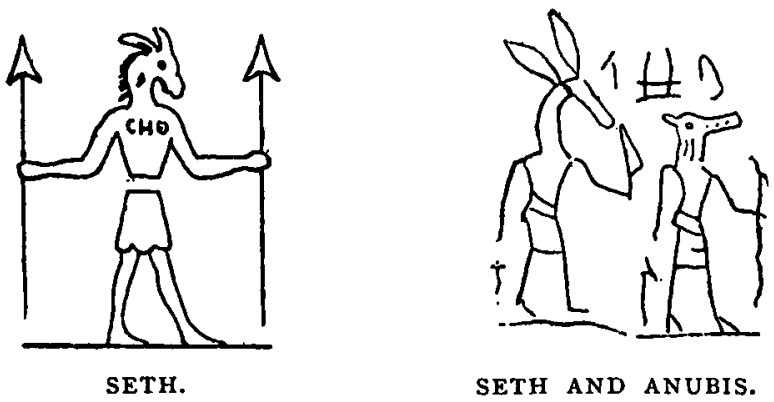

SETH AND ANUBIS.

450

the ass. His formidable braying is considered prophetic in folklore traditions, and this belief is extended to the neighing of the horse, an animal which supplants the ass though it does not appear in the history of the Orient unti] later. We remember that according to Herodotus, Darius was created king on account of the neighing of his horse. In Bible folklore, Balaam's she-ass was endowed with the gift of prophecy and there are scattered traditions still extant which prove that Yahveh as well as the war god Seth of the Semitic invaders in lower Egypt was assheaded.

"The first and second lines would be more literal as follows:

"With the jaw-bone of an ass

I'm massing them in masses."

6 ה The word is also transliterated hakkore; but the $\mathrm{k}$-sound is sharp and is commonly transcribed $q$. 
THE GATES OF GAZA.

It is an ancient Babylonian notion that the sun-god enters the inhabited world in the morning through two pillars which accordingly are erected in every Semitic temple. Even in the temple at Jerusalem the two brazen pillars were never missing, although their meaning had in later times been entirely lost sight of. To Phœenician

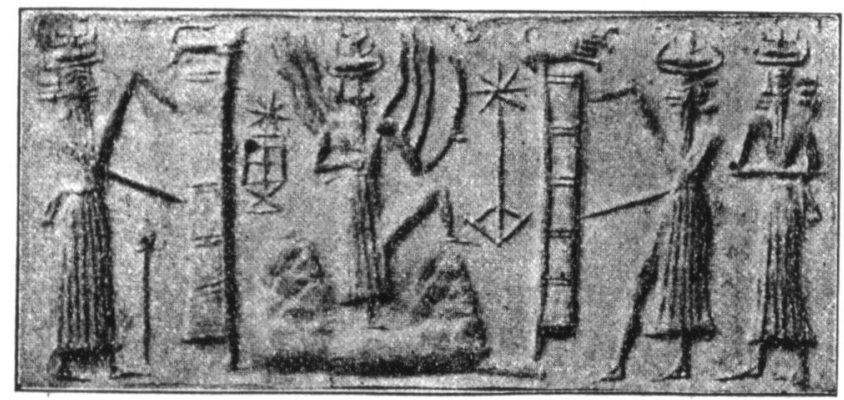

THE GATES OF HEAVEN OPENED TO SHAMASH.

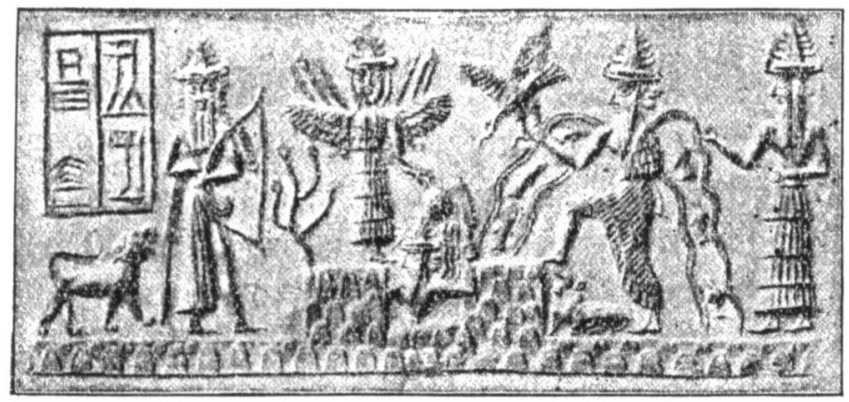

THE BABYLONIAN PROTOTYPE OF THE PILLARS OF HERACLES. 2037

sailors it was quite natural that the two rocks at the strait of Gibraltar should be considered as the two pillars of Melkarth through which the sun was supposed to pass on his descent into the underworld. It is again Diodorus who tells us (IV, 3) that Heracles put up the two mountains at the end of the Mediterranean which have, accord- 
ingly, been called after him the "Pillars of Hercules," down to Tarik's time, ${ }^{1}$ and should the question arise, How is it possible that the two pillars in the east are found also in the west, or that the pillars in the west should also be found in the east, the answer suggests itself that in the night the sun-god had carried them from one place to the other. In this way Samson's peculiarly unpractical joke finds a natural explanation, if regarded as a mythical event.

\section{THE WEB OF DELILAH.}

The accounts that Samson was bound and that he freed himself as if by the heat of fire are easily explained as incidents of a solar myth. Nature is ice-bound in winter, but with the awakening of spring the fetters melt away. The vinding is repeated, for during the fall months the inroads of winter become more and more serious. The hero frees himself three times before he is permanently fettered.

When Delilah tried to bind her lover, Samson said to her: "If thou shouldst weave the seven braids of my hair into the web and beat it up with the pin my strength would leave me." And she applied this method, but Samson "pulled up the loom with the web"-and we may add that Delilah's web was torn and flew all over the fields. If we remember that Delilah (like Samson) is a mythical figure and that the threads of her loom are to be woven into the rays of the sun, we shall at once find the proper explanation of the web which can be nothing else than the gossamer of autumn. Gossamer is also called Mary's yarn, and though the original meaning of the word is lost, we still know, that it has something to do with the web of some pagan goddess, or fairy. When the gossamer flies over the field we know that winter is near. It is the last snare

'The present name Gebr al Tarik, or Gibraltar, means "Rock of Tarik." 
that the sun-god has broken and torn to tatters. The enchantress will now shear his locks and then his strength will be gone.

\section{SAMSON'S SEVEN BRAIDS.}

Nothing can be more suggestive of Samson's solar character than the loss of his strength. The hair of the sun-god is commonly interpreted to be the rays of light that surround the sun, and Apollo is called by Homer (II. $\mathrm{XX}, 39$ ) "he of unshorn hair," which translated into Hebrew would mean the Nazir. Samson's hair is put up
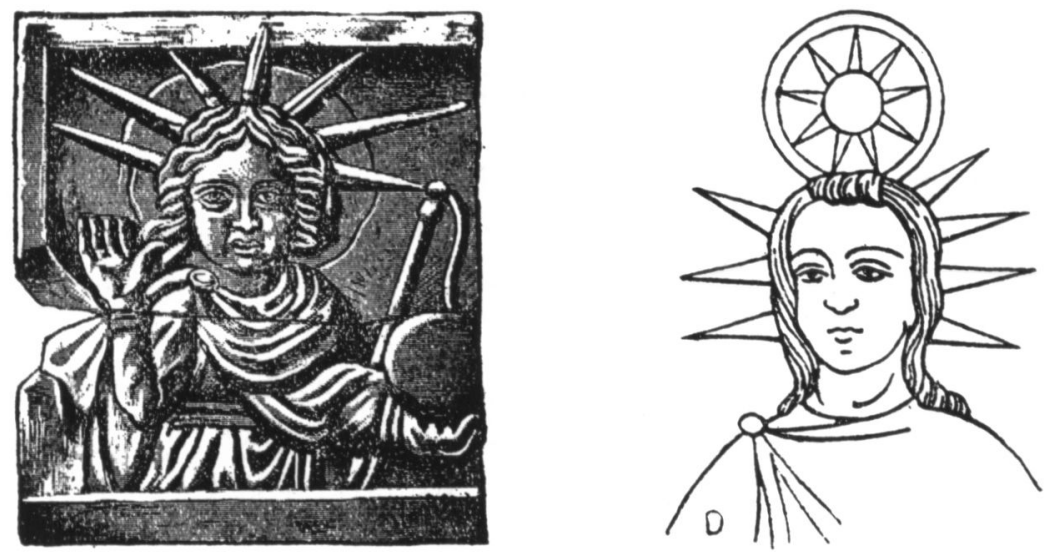

SUN-GOD WITH SEVEN-RAYED HALO.

Mithraic Monument and Etruscan Wall-painting.

in seven braids in the style of the sun-god who in one of the Mithraic monuments (reproduced by Cumont, Textes et Monuments, p. 202) is represented with seven rays, characterizing the mysterious power of the seven planetary gods. The loss of Samson's strength is due to the fact that he is deprived of his hair. The name of the traitress Delilah is symbolical and means "the weakening or debilitating one." Finally Samson is blinded, (the sun loses his light), and when he dies he stands between the 
two pillars of sunset, at Gaza, the most western city in Danite geography.

THE ONE-EYED ONE.

We know that the German god Wodan had one eye only, because there is only one sun in the heavens, and we are told in Teutonic mythology that Wodan had pawned his other eye to Mimer, the god of water. The second eye of Wodan is the reflection of the sun in the ocean. In consideration of the fact that the sun is the one-eyed god, it is noteworthy that the dying Samson exclaims: "I will avenge myself on the Philistines for one of my two eyes." The authorized version ignores this feature and translates "for my two eyes," and the current interpretation of Hebrew scholars (as stated by Professor Moore in the Polychrome Bible) is the idea that "the destruction of all these Philistines could be but a partial retaliation" which, if this interpretation were admissible, would only add to the unsatisfactory character of the conclusion of the Samson story. We believe that the original story knew a reason why Samson was one-eyed and the last prayer of Samson, which is a piece of poetry, must be regarded as a quotation from an ancient epic representing a more primitive tradition. Samson's prayer reads as follows:

"Adonai Yahveh

Remember me

And strengthen me.

Yea! once more now ;

Elohim !

And I wreak vengeance

For one of my two eyes

On the Philistines."

$$
\begin{aligned}
& \text { צוּר }
\end{aligned}
$$

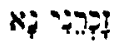

$$
\begin{aligned}
& \text { אי }
\end{aligned}
$$

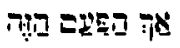

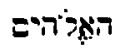

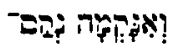

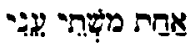

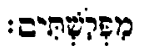

The poetical fervor of this passage, especially the rhyme, Zakreni na ve hazqeni na, so rare in Hebrew lit- 
erature, has been most happily imitated by $E$. Meyer, whose version runs thus:

"O merke mich doch,
Und stärke mich doch
Nur diesmal noch,
O du mein Gott!
Damit ich nehme
Auf einmal Rache
Für meine zwei Augen
An den Philistern!"

It is, however, barely permissible for Meyer to translate the word which means "one," by auf einmal in the sense of "all at once" whereby he avoids the difficulty of a literal rendering, implying that Samson takes revenge "for one of his two eyes."

THE LION AND THE DRAGON.

Among the twelve labors of Heracles we have one, consisting in the killing of a lion, which is common to all solar heroes of the Semites; and it is certainly not accidental that the Tyrian Melkarth and the Babylonian Izdubar are represented as tearing a lion in two and killing him without a weapon, merely with their hands, just as Samson does in the Biblical story. In Greece the lion's skin is the typical dress of Heracles.

Northern solar heroes fight a monster or a dragon, the symbol of swamps and fogs. This is instanced in the Beowulf legend, in the Siegfried Story, and in the fight of Thor with the serpent Jörmungander. But in the Samson story the fight with a dragon is missing, which may be regarded as an evidence of its ancient date. It is an indication that the Biblical tale is purely Semitic and uninfluenced by Aryan thought.

The Greek Heracles may originally have been an Aryan solar hero, a Siegfried, whose character was modified by the importation of Semitic features; or he may have 


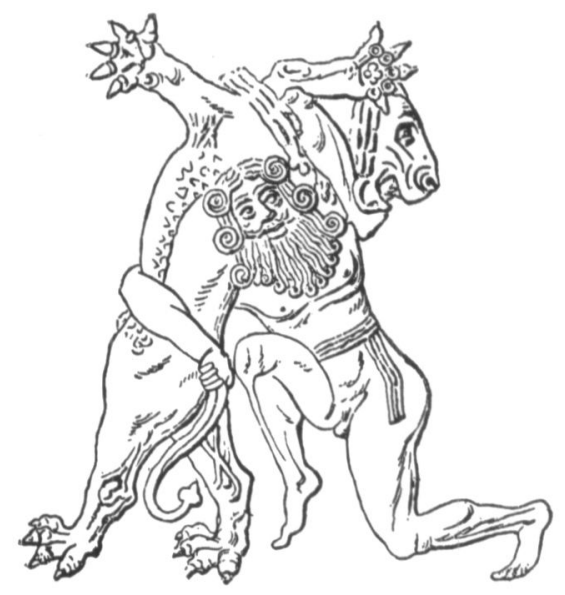

LION-KILLING HERO OF KHORSABAD.

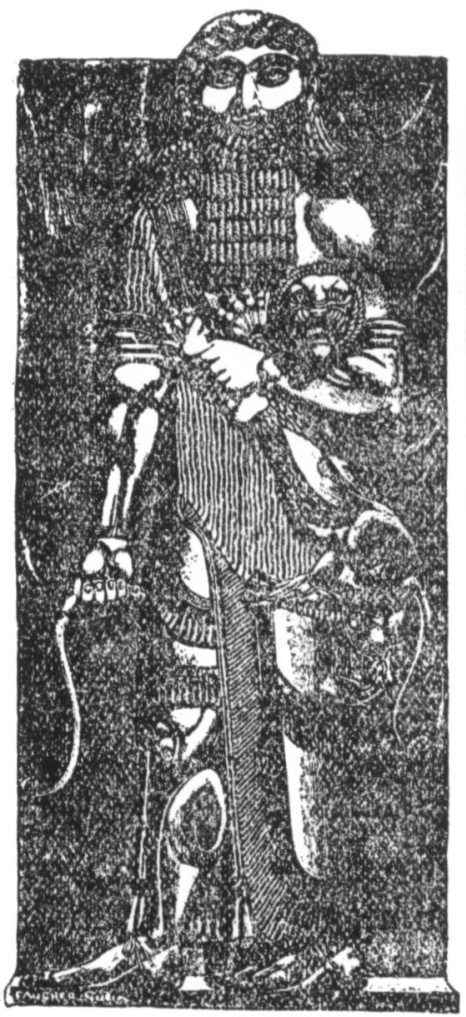

IZDUBAR STRANGLING A LION.

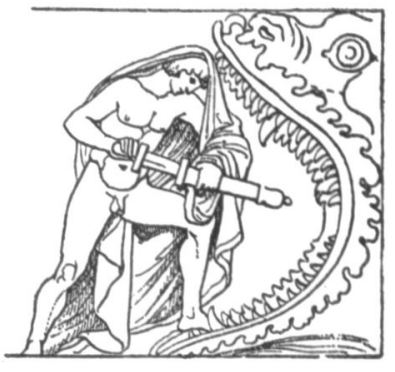

HERACLES ENTERING THE DRAGON.

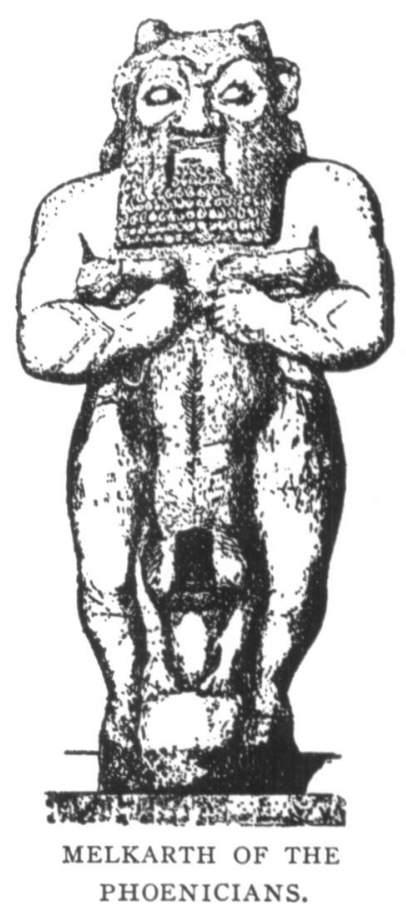


been the Semitic solar hero who became thoroughly Hellenized in Greece. Every one of these solar heroes has become a typical exponent of the nation to which he belongs, and so Samson remains a genuine Hebrew figure, yet he typifies the archaic and prehistoric age, not the more civilized period of later Judaism with its purer faith and higher morality.

We can in this connection only indicate that the similarity of Heracles to Izdubar is commonly conceded not only in general, but also in some important details.

Izdubar is frequently identified with Nimrod, and we can not doubt that the Biblical Nimrod contains some features of the Izdubar story. Either one is a "great hunter before the Lord," and the beginning of Izdubar's kingdom, as that of Nimrod, is "Babel and Erech and Akkad, and Calneh, in the land of Shinar." It is possible that Nimrod is an appellative of Izdubar. The name has been explained as "Bright Light.".

The name Izdubar recalls the nature of Mithras, who in the later development of Mazdaism plays approximately the part of Christ in Christianity. Mithras means "Splendor," and many mythological features of Mithraistic traditions indicate that he also is a personification of the sun and a deification of all the blessings which have found in the sun an appropriate symbolization.

The Izdubar epic as well as the Heracles myth treat the question of immortality, and though it seems that Izdubar (at least so far as the twelve tablets go) does not succeed in attaining his aim, we still see that the problem of immortality is the pivot of the whole poem. The Heracles myth is somewhat further developed for the hero surmounts all difficulties, and, though he must die, he attains

${ }^{1}$ Gen. x. 10.

'Roscher's Lex. d. gr. u. r. Myth., II, p. 773. 
Olympus and is there received into the circle of the celestial gods.

Most Assyriologists agree that the sun's passage through the twelve signs of the zodiac has furnished the original meaning for the stories told in the twelve tablets of the Izdubar epic.
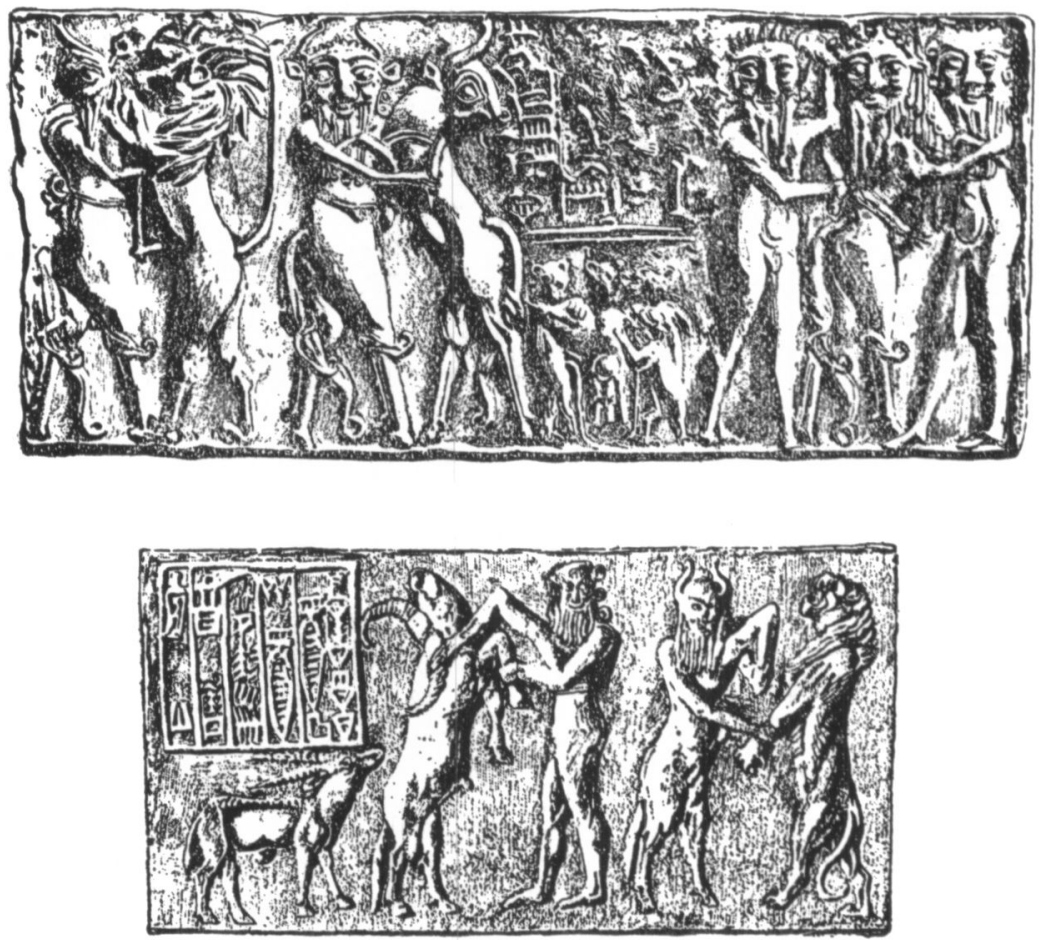

\section{IZDUBAR AND IMMORTALITY.}

The death of Heracles and also of Melkarth is represented as a suicide which is regarded as a self-sacrifice, and the same is true of Samson. He goes to death voluntarily, breaking down the temple of Dagon with the intention of slaying with him a great number of the oppres- 

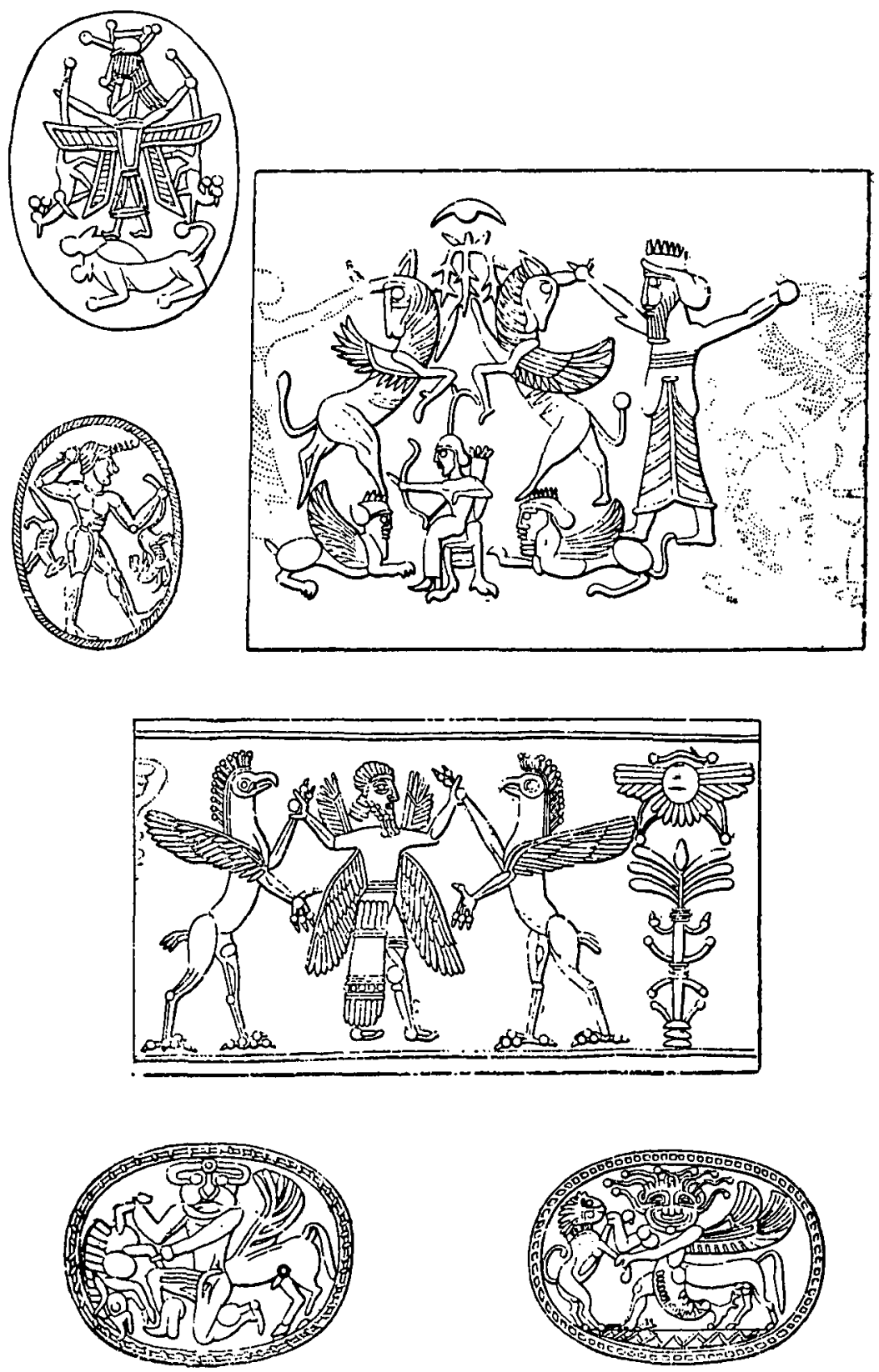

THE ADVENTURES OF IZDUBAR.

From ancient monuments. 
sors of his people. He knew that the edifice was filled with the lords of the Philistines, and it is expressly stated that on the roof alone there were three thousand men and women. The tacit implication is that the Philistines were weakened to such an extent that although the Israelites had not been freed, the Gentile authorities could no longer suppress them as mightily as before, and so it was fulfilled that Samson should "begin to deliver Israel out of the hand of the Philistines."

The end of Samson is the main point in which a comparison of the Hebrew hero with Heracles and Izdubar breaks down, for it is characteristic of pagan solar myths

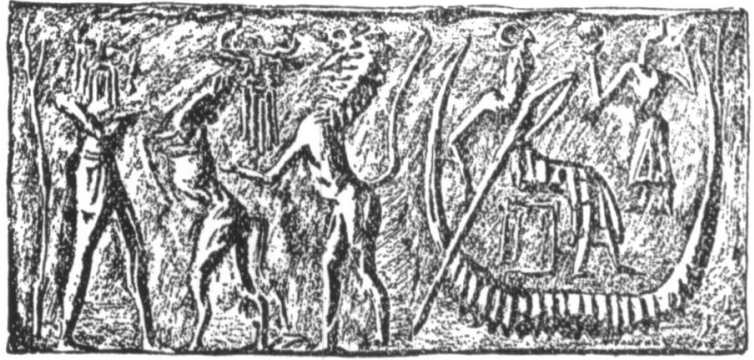

IZDUBAR AND ARAD-EA.

that the sun-god goes down to Sheol, or whatever may be the name of the world of the dead, and returns thence to the world of the living. Not only Heracles descends to Hades, but also other heroes of the same type, Odysseus, Orpheus, Fneas, etc., and the same is stated of Izdubar. The acquisition of immortality is the aim of both the Greek and the Babylonian heroes. In his anxiety to find his dead friend Eabani, Izdubar goes in search for the land of no return, and arrives at the coast, but the Queen of the Sea informs him that none but Shamash, the god of the sun, has ever crossed the ocean. However, Izdubar is persistent and is finally permitted to venture on the sea in company 
with the ferry-man, Arad-Ea, the Babylonian Charon. ${ }^{1}$ They reach the Isles of the Blest and while remaining in the ferry Izdubar speaks with his friend, who gives him information concerning the fate of the dead. Eabani thinks that the hero could not endure the description, but he comforts him with the thought that those who receive proper funeral rites will be well taken care of. Suffering from leprosy Izdubar seeks the water of life and the plant of life. He is healed from leprosy through the assistance of Sitnapishtim, and he finds the plant which he calls "as an old man he is changed into a youth," but by some mishap he loses it again.

When Heracles started out in search for the immortality-giving apples of the Hesperides, he encountered also the difficulty of crossing the ocean, and he succeeded only because the sun-god allowed him to use his bark.

Izdubar after death becomes a god, and Heracles too is welcomed in Olympus, but Samson's career ends with his life.

\section{SAMSON AND HERACLES.}

It is characteristic that while Heracles, the hero of a cosmopolitan nation, is regarded as the saviour of mankind who travels all over the inhabited earth, Samson is the saviour only of the tribe of Dan, and all his deeds are accomplished within the small radius of the tribe's political horizon. He is born in Zorah and he dies in Gaza.

It is customary even among critical minds to speak with admiration of the literary beauty and grandeur of the Samson story. Steinthal among others has devoted a number of pages to its praise, and I will not deny that especially the oldest and most original passages are ani-

${ }^{1}$ The Greeks owe their ideas concerning the other world mainly to the Egyptians, and so the names "Charon" and "Elysium" are Egyptian. The former simply means "ferry-man" and the latter is the Egyptian Aalu, the Fields of the Blest,-also spelled Aaru. 
mated by a truly poetic spirit, but judging the work in its present form I can only regret the censorship of its Deuteronomic editor, for I believe that the passages which he has cut out as mythological, have been the most valuable, the most interesting, and also the most religious part of the legend. They are now lost beyond hope of recovery, and so the hero of a primitive faith that was animated by a belief in immortality, has become a mere country lout and a tough, who conscious of his physical strength is always ready for a brawl, and we feel the delight of the narrator as well as his audience when Samson finds a pretext to kill indiscriminately some thirty or a thousand Philistines. Even considered from the standpoint of Israelitic patriotism he has done nothing to lift his nation to a higher plane or a nobler conception of life.

How much higher ranges the Greek Heracles, who in spite of the primitive crudeness of the original myth, has been idealized by Greek poets and philosophers into a pattern of highminded virtue!

As early as the seventh century before Christ the poet Peisander wrote an apotheosis of Heracles, called the Heracley, and later Greek authors, such men as Xenophon and Prodicus, ${ }^{1}$ regarded him as an incarnation of divine perfection. It was said of Heracles that he came to the parting of the ways of life and he chose the difficult and steep, the way of virtue in preference to the broad and easy road to vice. And since Heracles had become the ideal of Greek youth, it became customary to look upon the details of the old myth as mere perversions of a deeper religious truth, supposed to be the original. Epictetus who calls Heracles a saviour, and the son of Zeus, says: "Do you believe the fables of Homer?"

Seneca speaks of Heracles as the ideal of the good man who lives exclusively for the welfare of mankind.

'Xen., Mem. II, I; Plato, Symp., p. 177 B. 
Contrasting him to Alexander the Great, the conqueror of Asia, he says (De Benef., I, I4):

"Heracles never gained victories for himself. He wandered through the circles of the earth, not as a conqueror, but as a protector. What, indeed, should the enemy of the wicked, the defensor of the good, the peace-bringer, conquer for himself either on land or sea!"

Epictetus praises Heracles frequently and declares that the evils which he combated served to elicit his virtues, and were intended to try him $(I, 6)$. Zeus, who is identi-

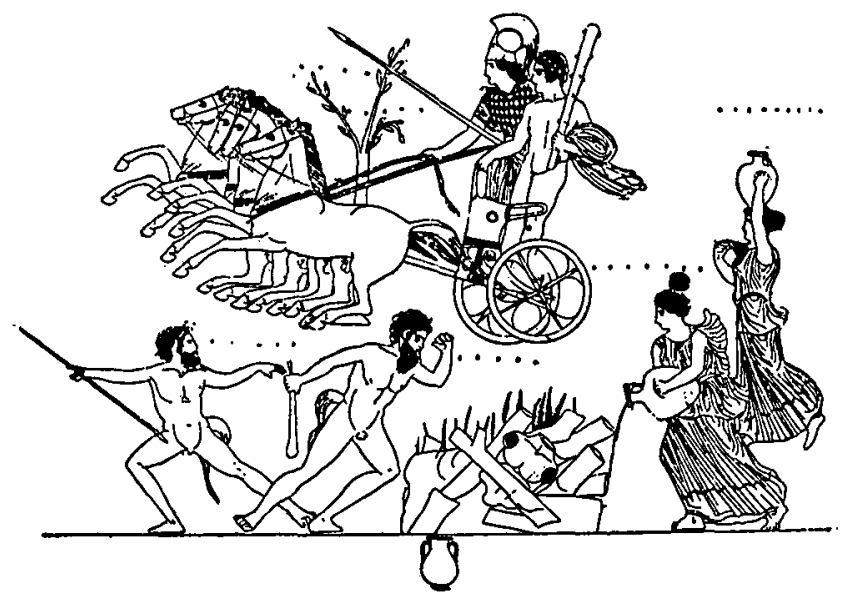

THE ASCENT OF HERACLES TO OLYMPUS.

Ancient vase picture.

fied with God, is called his father and Heracles is said to be his son (III, 26). Heracles, when obliged to leave his children, knew them to be in the care of God. Epictetus says (III, 24):

"He knew that no man is an orphan, but that there is a father always and constantly for all of them. He had not only heard the words that Zeus was the father of men, for he regarded him as his father and called him such; and looking up to him he did what Zeus did. Therefore he could live happily everywhere." 
The Samson story breaks off very abruptly and leaves a very unsatisfactory ending in its present form, the only comfort being that in his death the hero kills an incredible number of Philistines. If this had been all, the Biblical tale would simply be the record of a dearly bought victory of the Philistines.

However, we must take into consideration,-and the significance of this point should not be underrated,-that Christians look upon Samson as one of the prototypes of

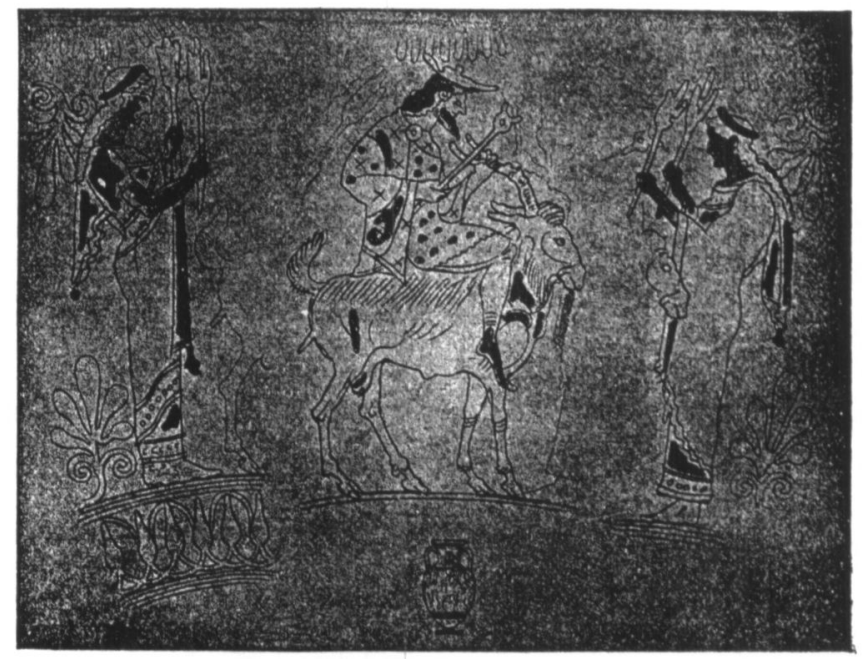

DESCENT OF DIONYSUS TO HADES.

Christ. Yet, strange to say, the point which alone could have made Samson a prototype of Christ is missing in the Samson story.

Prototype means a first or imperfect and only tentative type. All solar heroes are prototypes of Christ, and when the fulfilment of the times focused all pre-Christian religions into one, everything worthy and good in the prototypes of Christ was transferred upon Jesus whom the Church accepted as the fulfilment. In this perspective the 
Samson story seems to regain its original pagan significance as symbolizing man's hope for immortality.

The saviours and heroes of Greek and Roman mythology (Heracles, Dionysus, Orpheus, Æneas etc.), had gone down into the domain of Hades and returned to the land of the living; so it was a predetermined doctrine that Jesus before he could be recognized as the Christ, had to descend to hell and rise again from the tomb.

The original narrative of the Samson story must have ended in the glorious return of the hero to life, but the Biblical account knows nothing of it.

THE DYING GOD.

There are a number of incidental features in the Sam. son legend that are occasionally met with in kindred tales of saviours, dying gods, sacrificial divinities and solar heroes. They have not been mentioned before, because they are difficult to classify and so we group them here together as a collection of stray observations having one common point of issue, the fate of the saviour-god who lives and dies for mankind.

The people of a primitive age formed their idea of a saviour-god according to their religious convictions, traditions, expectations and especially their superstitions, all of which had become incorporated in the performance of their annual festivals. When the time came that they expected a Messiah or a Saviour, they naturally measured those figures of stories or perhaps also of natural life, with the notions they thus attributed to the ideal formed of him; and as soon as some hero, historical or legendary, became a candidate for the honor of being recognized as a godman his admirers naturally ascribed to him all those features which were deemed the indispensable characteristics of the god.

We do not say that the life of Jesus, especially his pas- 
sion and crucifixion were unhistorical; on the contrary we believe firmly that the nucleus of the Gospel stories is based upon fact, but we insist that the Gospel writers had in mind a typical, albeit vague, idea of the traditional conception of the god-man, and they interpreted the facts with a tendency which consciously or unconsciously dominated their minds, that they had to prove that Jesus was the Christ and that both his personality and his destiny fulfilled all the conditions of the current expectations. Thereby they incorporated inadvertently and sometimes purposely all

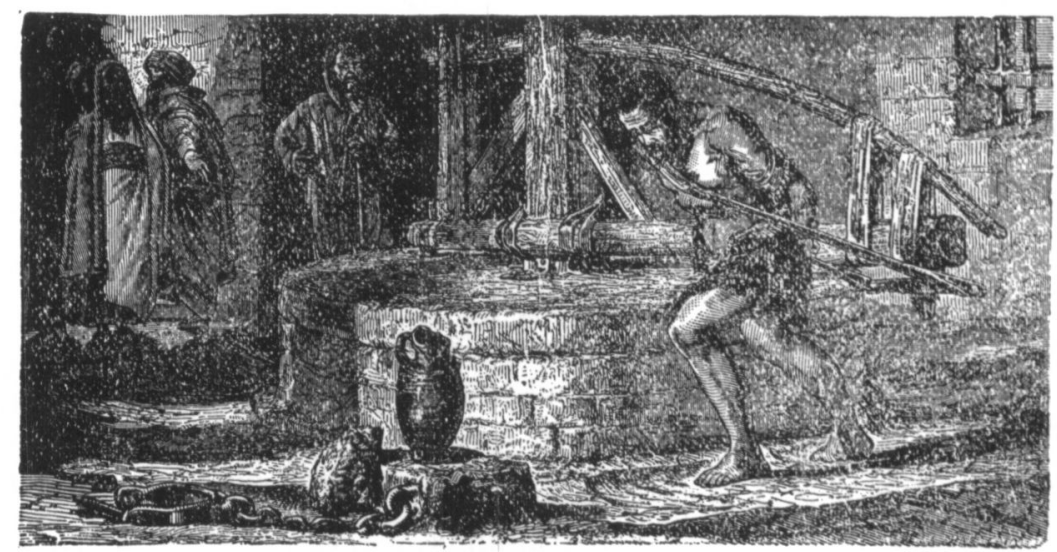

SAMSON'S DRUDGERY.

those features which in their time were deemed indispensable characteristics of the Saviour.

We notice that Heracles is made a servant and he is bound by his destiny to accomplish the twelve labors for the weal of mankind. The underlying idea is that the sun drudges as a slave in the ministry of our needs; and so Samson too is degraded into a slave and set to turning a mill. It is expressly stated also of Christ (Phil. ii. 7) that he "took upon him the form of a servant."

The explanation of the unhappy fate of the dying god receives different versions in different stories, but it is 
natural that he is always represented as the innocent victim of treachery. Judas is made responsible for the crucifixion of Jesus, and Samson succumbs to the wiles of the treacherous Delilah. The legendary character of the story appears also in the fact that any ordinary mortal would have been on his guard against the falsehoods of his paramour, but in myths and legends the destiny of a man is determined by other conditions, and so he is represented as incredibly stupid and absolutely blind to the snares laid for him. On the other hand, Delilah as well as the Philistines ought to have had other methods to find out Samson's secret.

Berosus tells us of Babylonian customs that "during the five days of the festival called the Sacaea, a prisoner condemned to death was dressed in the king's robes, seated on the king's throne, allowed to eat, drink, and order whatever he chose, and even permitted to sleep with the king's concubines. But at the end of five days he was stripped of his royal insignia, scourged and hanged or crucified."3 This feast was celebrated to represent dramatically the fate of the dying god in the same spirit and a similar fashion as was the custom among the Aztecs of Central America and the Khonds of Bengal.

This Babylonian rite is apparently, as Mr. Frazer suggests, ${ }^{4}$ a further evolution of a more ancient custom that is still practiced among the savage tribes of Africa, according to which the king, who is believed to be an incarnation of the deity, usually the god of life, or of the sun, or heaven, is sacrificed in his best years and before his physical power can give out. Mr. Frazer says:

"We must not forget that the king is slain in his character of a god, his death, and resurrection, as the only means of perpetuating the divine life unimpaired, being

See J. G. Frazer, The Golden Bough, Vol. II, pp. 24 ff.

'Ibid., II, 240 ff. 
deemed necessary for the salvation of his people and the world."

With the advance of civilization the old custom was modified. Mr. Frazer says:

"When the time drew near for the king to be put to death, he abdicated for a few days, during which a temporary king reigned and suffered in his stead. At first the temporary king may have been an innocent person, possibly a member of the king's own family; but with the growth of civilization, the sacrifice of an innocent person would be revolting to the public sentiment, and accordingly a condemned criminal would be invested with the brief and fatal sovereignty."

Finally even the vicarious sacrifice of a substitute king was abolished, and either replaced by an animal victim or merely acted on the stage in a dramatic performance.

Though the victim is a god, or rather the representation or incarnation of the deity, he is to be abandoned to the most dreadful fate of death, and so we meet with a statement that in the last moment he is forsaken by his god. As Christ cries out "Eli, Eli, lama sabachthani," so we learn that Yahveh forsook Samson and his strength was gone.

A special endeavor is made to have the sacrifice voluntary, and this is done among the Aztecs by intoxicating the victim with drinks and with honors and slaying him before he has a chance to give an ill-omened sign of regret. At the same time the people must have come into possession of the person of the victim in a legal way. Accordingly it is insisted on that he has to be purchased with money and the price must be paid before the sacrifice is performed. This feature is evident in the ritual of the Khonds and is not absent either in the Christ story where Judas receives the thirty pieces of silver, nor in the Samson story in which a sum of money is paid to Delilah. 
The idea that no atonement of sin is possible without the shedding of blood is common to all pre-Christian religions (with the sole exception of Buddhism), and even Christianity still clings to it, as we read in Hebrews ix. 22, "without shedding of blood is no remission."

The old Mexicans slew their god and ate him, which is a symbolical act indicating that we live on the deity, be it the god of vegetation or any other life-spending source of nature. Originally the harvest god is thought present in the very cerials, and in partaking of food we partake of the god himself. From this standpoint it was deemed essential that the devotees should eat the flesh and drink the blood ${ }^{\bar{s}}$ of the god and we cannot doubt that in the age of savagery, this ritual was literally performed, horrible though it must appear to modern mankind that condemns cannibalism as the most detestable abomination. In place of the human representative of the god we find in the ceremonies of a less savage age a substitute of some kind, either a sacrificial animal or a sacrificial bread offering, which latter was freqently kneaded in the shape of the god incarnation. A ceremony in which the figure of a god made of dough is killed and then sacramentally eaten is still performed in Tibet, and we can not doubt that the original conception of the Lord's Supper is an echo of this ancient rite of eating the god, which was deemed an essential part of the feast held in his honor.

The same idea is very emphatically expressed in John vi. 53-57: "Then Jesus said unto them, Verily, verily, I say unto you, Except ye eat the flesh of the Son of man, and drink his blood, ye have no life in you. Whoso eateth my flesh, and drinketh my blood, hath eternal life; and I will raise him up at the last day. For my flesh is meat indeed, and my blood is drink indeed. He that eateth my

\footnotetext{
xliv, I I.

"Even the Old Testament speaks of "the blood of the grapes." See Gen.
} 
flesh and drinketh my blood, dwelleth in me, and $I$ in him. As the living Father hath sent me, and I live by the Father: so he that eateth me, even he shall live by me."

The great progress of Christianity consisted in the practical abolition of all blood-sacrifices as well as the actual partaking of the flesh and blood of the victim. The idea of the significance of blood and the shedding of blood was too firmly rooted in the minds of the large masses of mankind simply to be set aside as was done in India by the Buddha. Acknowledging the force of the ancient religions, Christianity overcame them by pointing out that the atonement was now accomplished for all time through the death of Christ, and the sacrament of partaking of the very flesh and blood of the god was sufficiently performed by the substitution of sanctified bread and wine. This satisfied all the pagan claims without continuing the barbarous ceremony.

If the original Samson story contained anything of this kind it would have been so offensive to the redactor that he would not have tolerated it, and so its absence is naturally explained.

How tenacious traditions are! The old ritual of a human sacrifice has been abandoned but the festival is still continued to the present day in the form of the carnival which not without a good historical reason precedes in the annals of the Christian calendar the celebration of the passion of Christ. The king of the carnival was originally the victim that was to undergo the torture of a sacrificial death, but shortly before his doom he enjoyed the honors of a mock-kingdom. We read of Christ that they "put on him a scarlet robe. And when they had platted a crown of thorns, they put it upon his head, and a reed in his right hand; and they bowed the knee before him, and mocked him, saying, Hail, King of the Jews!"

It can scarcely be accidental that the Philistines are 
said to have had Samson produced at their festival, "that he might make them sport."

We cannot doubt that the king of the Sacæan festival was conducted through the city in festive procession, and we are inclined to think that this feature of the ceremony formed one of the most popular and impressive parts of the feast. Even this has been preserved in both the story of Christ and latter-day customs, such as carnival processions. The Gospel stories dwell with special emphasis on the triumphal entry of Jesus into Jerusalem, and some of our Christian artists have indeed represented the scene as a theatrical pageant which is specially notable in Doré's well-known painting.

Our carnivals have originated from dramatic representations and are a secular treatment of the same religious ceremony, which in the Church developed as the so-called mystery-play, originally a dramatic performance of the Easter story.

In the age of Constantine Christianity became the state religion of the Roman empire. This event, to be sure, Christianized the broad masses of the people but it introduced at the same time a number of pagan features and pagan beliefs into the life of the Church. It must have been in this age that the Church continued the practice of making the Easter ritual a dramatic performance after the precedence of the Attis and Tammuz festivals, the former of which, as we learn from Firmicus, was celebrated on the first day of spring while his resuscitation to life was placed two days later.

How much the Christian ceremonies preserve of the ancient pagan traditions appears also from the significance that light plays in the Easter ritual. In the Greek Church the priest announces the beginning of the feast with the words: "The celestial fire has come down from the clouds; the holy candle is lit." 
There is an additional point worth mentioning. The word sakhaq, ${ }^{\theta}$ which in English versions is commonly translated "to make sport," includes the meaning of singing, dancing, and playing on musical instruments, in the same way that the word "play" is also used in both senses. ${ }^{7}$ Accordingly Luther translates the term by spielen, and the traditional interpretation as represented in some Biblical pictures makes Samson play on a stringed instrument which proves that our popular conception of him is unconsciously associated with Apollo, the solar god, who is at the same time a master of the lute.

These notes on comparative saviour-lore throw a light also on the construction of the Gospel story of Christ in which we find so many echoes of ancient pagan saviours.

Samson, the solar hero and as such a prototype of Christ, was betrayed and sold for money; he drudged as a slave, and shortly before his death made sport before the Philistines. These incidents are minor points, but their introduction into the Samson legend can scarcely be regarded as accidental, when we bear in mind the significance which these same features possess in kindred stories where their connection with the underlying idea of the fate of the dying saviour-god has not yet been lost.

\section{SAMSON'S TOMB.}

Every province of Egypt had a sepulchre of Osiris. and the legend explained this by telling how his body had been cut into several pieces which were buried in these different places. Perhaps originally the priests of every sepulchre claimed for their fane that the entire body of Osiris rested there; for we know that some of the Greek gods, too, possessed tombs, and it is not impossible that ${ }^{6}$ poip

'For further particulars see Gesenius's Hebrew Dicitionary, German ed., Vol. II, p. 6r5. 
the same god possessed several tombs. We will not be mistaken if we look upon these tombs as cenotaphs, or empty sepulchres, not unlike Christian crypts, erected for the sole purpose of impressing the people with the reality of the god that had died and come to life again.

It is pretty certain that the names beginning with Beth, i. e., "house," indicate the presence of a temple. BethLehem is the city where stood the house of Laham (i. e., a temple of the god Laham) and in the same way Beth Shemesh must have been the site of the temple of the sun-

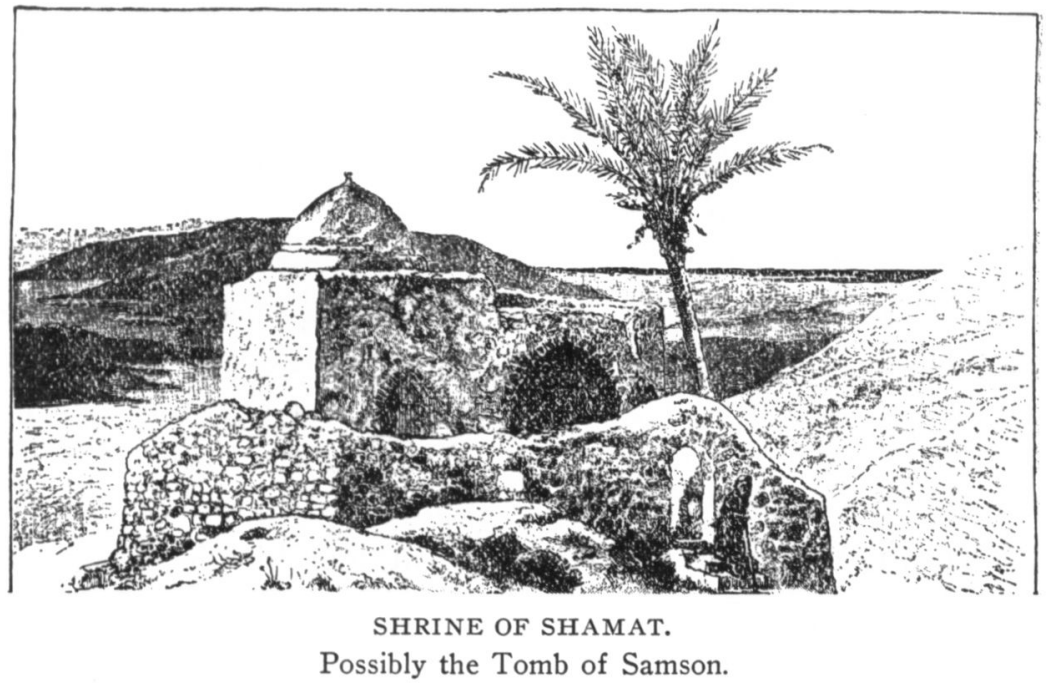

god, Shamash. It was situated right between Zorah and Eshtaol and we are told that there, too, (i. e., between Zorah and Eshtaol) was the tomb of the Manoah tribe where Samson lay buried. This sepulchre may have been near the temple of Shamash or may even have been connected with it, and the probability is that it was just as empty as were all the cenotaphs of Egyptian and other Gentile gods.

In the Recognitions of Clement $(\mathrm{X}, 23)$ it is stated 
that the tomb of Zeus is shown among the Cretans, and we read further (ibid. 24):

"But also the sepulchres of Jupiter's sons, who are regarded among the Gentiles as gods, are openly pointed out, one in one place, and another in another: that of Mercury at Hermopolis; that of the Cyprian Venus at Cyprus; that of Mars in Thrace; that of Bacchus at Thebes, where he is said to have been torn in pieces; that of Hercules at Tyre, where he was burnt with fire; that of Esculapius in Epidaurus."

\section{WHY THE RESURRECTION OF SAMSON WAS SUPPRESSED.}

Though the Samson legend must have been the ancient Hebrew myth of the adventures of the sun-god, all those extraordinary miracles which savor of pagan divinities have been reduced to deeds of human valor and among other things the most characteristic event of a mythological nature, Samson's resurrection, has been removed. I am convinced that in the original Samson epic the return of the hero from Sheol played a prominent part, for all pagan sun worshipers gloried in their god, because, although at nightfall he descends into hell, he comes out again the next morning unscathed. All sun-hero myths preach immortality on the argument that the sun loses his power in winter and is resuscitated to life in the spring.

The theme of the original Samson legend can only have been the same great legend which at all times and among all nations engrossed the attention of religious thinkers. It is an answer to the question "Is death the end of all?" The legend of the descent of the sun into Orcus and his triumphant return to life is the good tidings that proclaims the eternity of life, and the remarkable stories of the adventures of the sun, be it in the different countries over which he passed or in the several mansions in the sky, form 
an inexhaustible storehouse for all kinds of wondrous romance.

This same subject constitutes the most typical feature of all the most important and most popular myths of mankind. In fact we may consider it as the most characteristic type of pagan religion which is still reflected in fairy tales (such as the story of Psyche) and all kindred traditions. Everywhere we meet with a hero who is somehow the incarnation of the deity or a god that has temporarily assumed human form to appear on earth as a helper and saviour. We learn of his troubles and dangers, of the enemies who encompass him and gain an apparent victory over his cause, but finally he overcomes all evil and breaks through the doors of death gaining new life and new strength in his glorious resurrection. Nor is this characteristic feature of pagan myths limited to the sungod. It appears also in the sprouting and withering vegetation, which temporarily succumbs to the intrigues of winter but reappears victoriously every spring in the field.

It is a remarkable fact which has frequently been pointed out, that while Babylonians, Syrians, Phœnicians and Egyptians believed in immortality, the Old Testament contains no allusions to it. On the contrary, it denounces as an abomination the rites of Tammuz, the god who dies and rises to life again, and condemns to death all wizards and witches who after the fashion of mediums (as instanced in the story of the witch of Endor) used to summon and consult the spirits of the dead. The truth is that the priestly redactors were animated with a zeal for a pure monotheism and a contempt for all pagan institutions. They were convinced that Yahveh had revealed himself to Moses as the one and only true God, and so they looked upon all traces of polytheistic customs in their traditions as backsliding into the ways of idolatry. It is natural therefore that they would not countenance in their Scrip- 
tures such features or doctrines as would indicate that their fathers had sanctioned the fables of the Gentiles, and they would necessarily omit the resurrection story of Samson which reminded them so much of the resurrection of Tammuz.

The immortality idea could not be suppressed for any length of time and so it asserted itself again in the apocryphal books which constitute the most important link between Judaism and Christianity. They contain the seeds from which Christianity developed and also explain how later Judaism adopted a belief in the immortality of the soul, which, however, has been purified of the pagan elements attached to the Babylonian view, so closely connected with the mythology of Istar and Tammuz and the superstitious practices of spirit conjurors.

\section{THE REDACTION OF THE SAMSON STORY.}

The treatment of the Samson legend fairly characterizes the general work of a late redactor. It is firmly established that the leading minds among the Jews in the Babylonian exile were zealous monotheists. They hated mythology, polytheism, and the worship of idols in any form. They spurned the paganism of the surrounding nations as well as in their own tradition. And so in collecting their sacred literature, they edited the several scriptures in a rationalizing spirit. Far from being credulous, as freethinkers usually represent them, we insist that they were the rationalists, the freethinkers, and iconoclasts of their age. And so they either cut out the mythological element as pagan superstition or humanized its supernatural features, or explained pagan institutions as apostacy. ${ }^{1}$

${ }^{1}$ Such passages as Judges ii. 13 , or iii. 7 ; iv. I; viii. 38 , etc. are of Deuteronomic origin and, it seems to me, indicate omissions from the sources which the priestly redactor still had at his command. The original sources from which he drew his account were not yet purely monotheistic and must have related how the Israelites worshiped not only init but also Baal and 
It is characteristic of the Bible that with very few exceptions fables and folklore in their original form are absent, and the cosmological stories have been simplified into a dry report of a six days' work of creation, yet some traces of the originally mythological character of the ancient Hebrew legend have been preserved in the Old Testament, in spite of the attempt at their obliteration. ${ }^{2}$

Nothing was more odious to the reformers of Judaism than the pagan ideas incorporated in the Tammuz ritual, which consists in the bewailing of the dying god, and shortly afterward in the celebration of his resurrection, a kind of Babylonian Good Friday with its subsequent Easter festival. The absence in the Old Testament of any allusion to a belief in the immortality of the soul finds its easiest explanation in the theory that all references to it have been carefully removed, and so it is in keeping with the general tendency of the redactor's work that the Samson story should have been cut short where it became too similar to the myths of pagan deities such as Tammuz, Adonis, and Marduk, who descended into the realm of the dead, broke open the gates of hell, and returned victoriously to the land of the living. Thus the Samson story by being rationalized became a torso. It has been deprived of its original meaning and has simply been reduced to the story of a rollicking bravo, whose sole merit consists in having done great injury to the Philistines.

\section{CONCLUSION.}

From all that has been said of the Samson story we must grant that it resembles not only the pagan solar myths and the fate of the dying gods, but also the life of

Astarte. Our redactor ascribed all the misfortunes that befell Israel to the worship of other gods, and he selected with preference the heroes of Yahveh worship for national commendation.

"See the author's articles "The Fairy-Tale Element in the Bible," The Monist, XI, p. 405; and "The Babylonian and Hebrew Views of Man's Fate After Death," The Open Court, XV, p. 346. 
Christ in whom in the course of the religious development of mankind all these weird and mysterious notions have found their final expression. But the main event without which the story of the Crucified would be a tragedy-the resurrection-is missing in the Samson story.

While the Samson story as we have it is a torso, and can as such be regarded as satisfactory neither from a religious nor literary standpoint, it is nevertheless a most valuable relic in the history of the evolution of religious ideas. The story as it stands has no doubt been mutilated and has suffered from the hands of monotheistic zealots, who in their well-intentioned anxiety to cut out the pagan element have removed its most characteristic features, yet there is enough left to give an approximate idea of what the ideal of a divine incarnation had become in the phase of Danite civilization. We still feel the thrill with which narrator and hearer were warmed while thinking of the irresistible Samson. We enjoy the very sound of the $\mathrm{He}-$ brew original, most poetic in those fragments which must be deemed most ancient, and so we will naturally look with reverence upon this interesting religious document for we know that the hero who is represented by Heracles, Izdubar, Odysseus, Siegfried, Mithra and others, is a preliminary and tentative formation of that great ideal which found its final completion in the Christian idea of the Godman, Christ, the judge who at his second advent is to sit in judgment over the quick and the dead, the King of the world to come when there shall be no misery, no want nor worry, and no death.

There is one point only to be added for the purpose of anticipating a misconstruction of the significance of our results. The similarity of the Christ story to pagan legends does not lower Christianity to the level of paganism; but, on the contrary, it raises paganism to the dignity of genuine religion. Pagan myths, in spite of their crudities, 
are born of the same yearning, the same devotion, the same hopes. We do not say that paganism and Christianity are on the same level, for they are marked by decided differences. Paganism belongs to the period of nature worship while Christianity characterizes the age in which an appreciation of the soul establishes a contrast between nature and spirit. As a result of these differences the Christian version of the God-man discards all those features which are all too human and all too natural, and savor strongly of materialism, translating the story into that conception of spirituality which pervades the entire religious atmosphere of the age.

Our treatment of the Samson story conveys a lesson of no mean importance, and one that is gradually being recognized among leading theologians, namely that comparative religion and higher criticism will considerably modify our religious faith.

Some pious people in their well-intentioned anxiety for the holiest ideals of mankind denounce research as ungodly and shun it as if it were sinful and a work of the evil one. They foresee the coming change and feel a lack of strength to adapt themselves to it. Yet the change is unavoidable. It would be better for them had they less belief in the letter and more faith in the spirit. If the results of scientific investigation are wrong we need not worry, for they will soon be refuted; but if they be the truth, no power can prevail against them. And if they are true, they can not be evil, for the truth is of Godperhaps not of the God of a sectarian interpretation of religion, but of the God of truth, the God of honesty, the God of veracity, the God of science.

Science is not a human invention. Science is a revelation of God, and in the field of religion science is destined to accomplish the work of a great reformation. Science will mature our religious longings and purify our faith. 
Comparative religion will broaden us, and criticism is the refining furnace which will enable us to separate the gold from the dross.

With better and more exact knowledge we shall need a new interpretation of our faith, but the new interpretation will be as much the result of historical development as the present is the outcome of the past. The religion of the future will be in spirit the same as the religion of the past. Indeed, if we take mankind as a whole we can say that the religion of the future will be this selfsame religion of the past with such corrections or alterations as the present will have to add thereto.

We close with a quotation from the apocryphal book of Esdras ( 1 Esdras iv. 38), a passage which would have deserved a place in the canon. It reads:

"As for the truth, it endureth, and is always strong; it liveth and conquereth for evermore. With her there is no accepting of persons or rewards; but she doth the things that are just, and refraineth from all unjust and wicked things; and all men do well like of her works. Neither in her judgment is any unrighteousness; and she is the strength, kingdom, power, and majesty of all ages. Blessed be the God of Truth!" 